University of Rhode Island

DigitalCommons@URI

Research Papers by Undergraduate Students

Textiles, Fashion Merchandising and Design

$5-2020$

\title{
Social Media Influencers
}

Taylor Lennox

University of Rhode Island, Class of 2020

Follow this and additional works at: https://digitalcommons.uri.edu/tmd-research-undergrad

\section{Recommended Citation}

Lennox, Taylor, "Social Media Influencers" (2020). Research Papers by Undergraduate Students. Paper 2. https://digitalcommons.uri.edu/tmd-research-undergrad/2

This Seminar Paper is brought to you for free and open access by the Textiles, Fashion Merchandising and Design at DigitalCommons@URI. It has been accepted for inclusion in Research Papers by Undergraduate Students by an authorized administrator of DigitalCommons@URI. For more information, please contact digitalcommonsgroup@uri.edu. 


\section{Social Media Influencers \\ By Taylor Lennox}

TMD 461, Spring 2020

Instagram is an enjoyable app to share photos and videos of your life, friends, and family. You can gain inspiration on Instagram as well as shopping directly on the app. However, Instagram is also used as a major marketing tool for brands and businesses, as well as people. The Instagram influencer market is growing rapidly with over three million sponsored posts growing 48\% in 2019 (Hutchinson, 2019). The influencer industry is dominated by women, $84 \%$ of them to be exact. According to Social Media Today, most female influencers fall between the ages of 25-34 because social media influencing requires a business mindset, something that younger influencers may not fully understand yet. Fashion is the number one industry on Instagram with sponsored posts, followed by traveling, fitness, and beauty (Hutchinson, 2019). There are many elements that go into Instagram influencing: styling, photography, choosing with whom to work, locations, your account analytics, and much more. Focusing on how the industry works, how to create content, comparisons to other successful influencers, and how to monetize your business, I will be talking about how one can successfully break into the social media influencing field.

I accidentally fell down the rabbit hole of "Instagram influencing" over a year ago. This can be something people strive to do, or accidentally fall into such as I did. As a fashion student, I loved taking photos of my outfits or even just myself, sharing them on Instagram tagging the brands that I am wearing. I kept my Instagram as a business account simply because I was interested in my account's analytics. Most influencers label their accounts with their name and the title as "Public Figure", "Digital Creator", "Fashion Model", "Blogger", etc, but I pride my Instagram on being lighthearted and fun (overall kind of silly) so I label my account under the name "burgerkingangel" with the title "Cemetery". This has no impact on my account in general, it just lets me be able to see my analytics and has my email available to anyone who would like to contact me. In April 2019, Boohoo was the first brand that asked to work with me, and I still continue to work with them today. Boohoo was a brand I have shopped since high school, so I agreed and had my first brand deal. Once again, I did not influence prior to this so the adjustment to contractually creating content with deadlines was much different than making it for fun whenever I wanted. Boohoo even provided me with the opportunity to attend Vidcon in Anaheim, California over the summer. It was my first time in California and I got to stay in the creator hotel with established Youtubers, influencers, and more. I met many people on that trip, some Internet personalities that I looked up to, and it was such a great experience. Within that time and now, I worked with other brands like Tinder and Buxom Cosmetics for short campaigns with monetary compensation. I typically agree to deals like that if it simply provides 
money for a certain amount of Instagram posts, with no strings attached. More recently, I began a partnership with Calvin Klein in January of 2020. This is another partnership I love as much as Boohoo, providing me with once in a lifetime experiences. As the free products are a plus, I was able to travel to New York City to attend an exclusive pop-up shop and network with other influencers as well as create relationships with Calvin Klein employees. I was photographed by professional photographers and ended up on a massive billboard in Soho in a Calvin Klein One advertisement (their unisex fragrance). Calvin Klein is not afraid to promote small-scale influencers, which is something I really admire about their company.

I originally began my time on social media with Twitter in 8th grade as a One Direction fan account. This may sound odd and trivial but more people than you would expect began their careers with One Direction fan accounts, like influencer Orion Vanessa (688k followers), musician Camila Cabello (49.2M followers), musician Halsey (19.4M followers), and Tiktoker emmwee, or Emmy Hartman (998.8K followers). It was a community where you could connect with many people because you all had one common interest and the connections just grew and grew. From 8th

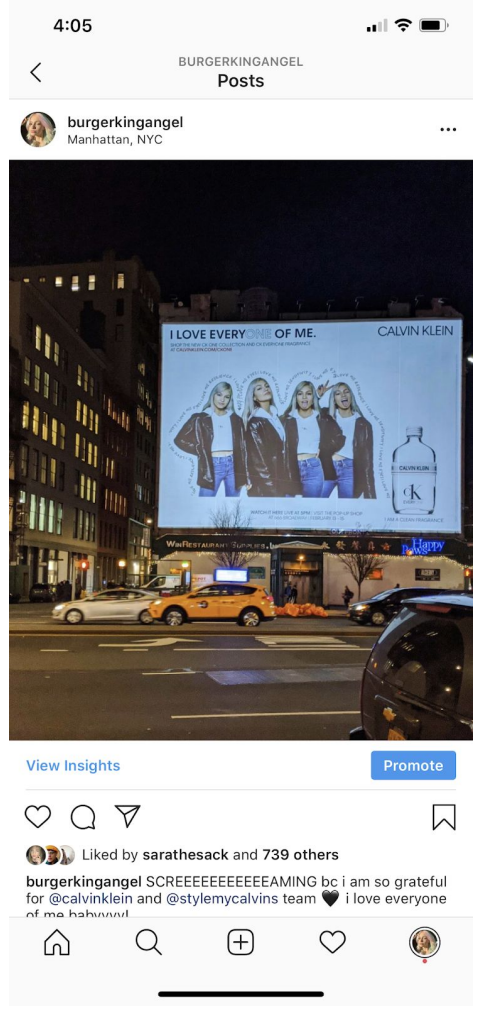
grade to the time I was a sophomore in high school I had accumulated 16K Twitter followers as a One Direction fan account, even followed by a member of One Direction. A lot of my followers carried over to Instagram and that is how I had a decent following as a high schooler from a small town in Massachusetts. In fact, compared to established influencers, I do not even have that many followers on Instagram, only 5.1K. Most of my following is on the newest social media app sensation, Tiktok. Tiktok is an app where you create minute or shorter videos simply about anything; comedy, fashion, your pet, makeup tutorials, celebrities, life hacks, and more. My Tiktoks are mostly loose comedy and I have 32K followers as of May 2020. These followers also can carry over to Instagram if they are interested enough. Once again, it goes to show your follower count is not the end of the world when it comes to Instagram influencing, you just need to be consistent and produce content your followers want to see. I fell into it accidentally and much differently than most, as this was not something I truly aspired to do, I just did it for fun. I post whatever I want on all social media accounts, being fashion related, some goofy photos, silly tweets, etc. A lot of people may accidentally put themselves into a social media box, thinking if they post fashion pictures that is all they are allowed to do or talk about. I believe because I gained most of my followers from comedy on Twitter and Tiktok, and then they come to Instagram and think "Oh, she fashionable too," so it is important I appeal to everyone.

There are many different elements that fall into creating sponsored content. Styling is my favorite. I love creating different fun outfits and incorporating things people would not think to pair with something. My style is definitely a bit all over the place, but that is how I like it. For example, I could wear a pink flowy dress with strawberries on it paired with pink boots one day, and chained black pants, a graphic tee, and chunky black Doc Marten boots the next day. My favorite way to style clothes is by contrasting the type of piece, while matching it to other 
elements in the outfit. For example, wearing black buckled pants with chunky black boots, but pairing it with a pastel pullover with kittens on it. Many influencers, including myself, gain a lot of style inspiration on Pinterest, making folders of outfits, makeup, hair, etc. I dye my hair fun colors all the time and my followers seem to enjoy it and always let me know their favorite style.

Once an outfit is decided on, I need to choose where to take the photos. The options are pretty small when I am at school in Rhode Island or home in Massachusetts. Preferably, I would rather take pictures in cities where there are more interesting things to look at, but when I do not have the option, I will usually go to the beach or try to hunt for interesting spots. Typically, when I go on a trip or do something exciting I make it a point to get an Instagram picture (or many pictures) so I can stock up on them and not miss any posting deadlines. It actually makes trips a lot easier and less stressful because I will already have everything I am wearing planned out, and just need to take a quick photo. This definitely all sounds superficial and downright unnecessary to those who do not "get it" or care about it. My parents, friends, and others comment or joke about how I need to put the phone down and just enjoy life, but I find my parents are now the ones to understand that this is essentially a job. People may stare and make comments because they do not know why you are taking an elaborate picture at Narragansett Town Beach on a Tuesday afternoon. But at the end of the day, it is a job, and it grows my Internet relevance to achieve bigger and better brand deals.

One of the hardest parts is finding someone to take the photo. A lot of my friends do not understand that I'm contractually obligated to meet a deadline, so they do not care to "get dressed to go out somewhere just to take a picture." It is much easier when I am on a trip, and people are more willing to have fun and take pictures. But if it is a regular day, it is a rare occasion anyone will want to help me make content. It would be much easier in a more "Internet lifestyle" accepting area where more people are in the same boat of having to make content, like in New York City or Los Angeles. I use my Instagram analytics to decide the best time to post

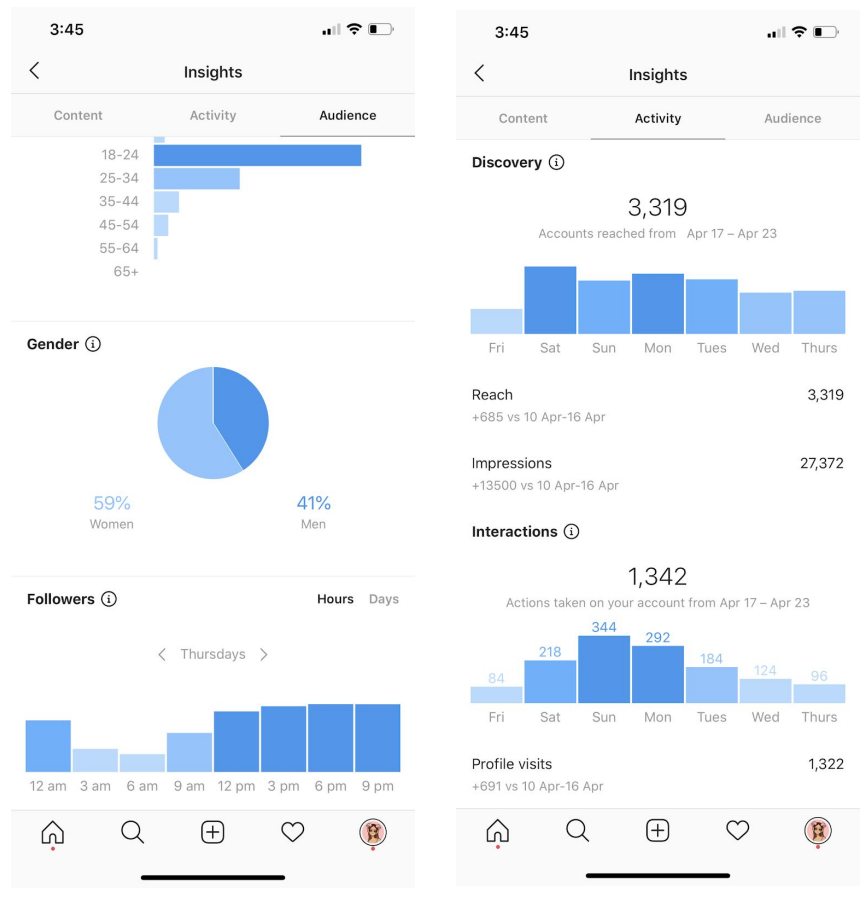
for optimal people to see it and interact. You can access this information on Instagram by being a business account and checking your insights. This tells you how many people have seen your posts, how many people have saved your posts, how many people have followed or unfollowed you, the top locations of your followers, age range, gender, and what days and times of the week your followers are most active. This is very helpful for not just influencers, but businesses to make marketing decisions. Making content during this time of COVID-19 has been difficult as well. Most of it is in my house, or outside of my house, which is my least favorite kind of content. It feels a bit ridiculous having to get ready for the day, take a photo, and then take all the clothes and makeup off. However, I am very lucky that my partnership with Boohoo is 
still active at this time. Affiliate social media marketing costs are being cut by many companies, ending many of their influencer programs due to COVID-19. Some companies that have cut their influencer programs at this time include Macy's, Dillard's, T.J. Maxx, and Ulta Beauty (Lieber, 2020). This is due to physical stores being closed, so consumers are cutting their costs on fashion. Because of this, these stores are not making their expected revenue, turning them to cut costs in social media marketing. I still have my partnership with Boohoo at this time because Boohoo is an online retailer so their revenue may not have been as affected compared to stores that depend on their physical locations, like department stores.

There are many different types of brand deals one can have with a company on Instagram. I weed through offers by typically partnering with brands that I have heard of before. For big brands like Calvin Klein and Boohoo, I do my posts in exchange for free products and occasional experiences. Experiences would be the trip to Vidcon in California with Boohoo or the NYC pop-up shop and billboard with Calvin Klein. I receive clothes each month that I pick out from Boohoo in exchange for three posts a month and PR packages from Calvin Klein with the release of new collections. You can also do your sponsored posts in exchange for payment. For example, I had a three month contract with Tinder for \$200 a month, for three posts a month. I also received free products from this brand deal in addition to payment. Another kind of brand deal is one that I will personally never do, but it is when a brand gives you a coupon code and you make commission off of whoever uses it. You have set sponsored post deadlines where you promote the products and your coupon code. I have never done a brand deal like this as it seems like it is too much work for not much payment. I find it to not be effective for a company to use this method because the influencer has nothing to lose if they suddenly stop doing your sponsored posts, but the company loses the free products they gave to the influencer.

As an influencer, I have gained quite a bit of free merchandise from gift boxes, PR packages, and the clothing I pick out. As I do not have the space to keep everything for myself, I choose to allocate what I gift, donate, or resell. Keeping sustainability in mind, I never throw away anything I am given; I will simply find it a new home.

While a lot of social media influencers are celebrities, there are definitely a fair amount who have created their platform on their own. For example, Emma Chamberlain is 18 years old and taking over the Internet at the moment as a social media influencer and Youtuber. She has $9.1 \mathrm{M}$ followers on Instagram and has partnered with major companies and even designer brands like Louis Vuitton, Calvin Klein, Aritzia, and more. Emma Chamberlain has gained her platform by catering to a younger audience with humor as well as fashion. Her target audience includes high schoolers and college students interested in lifestyle content and fashion, with humor in everything. I admire Emma Chamberlain because I think her "aesthetic" is also how I have gained my platform as well, but definitely on a smaller scale. Another influencer I personally admire is Amanda Steele. Amanda Steele is 20 years old and has always been a fashion, beauty, and lifestyle influencer on Instagram and Youtube. I remember watching her videos in high

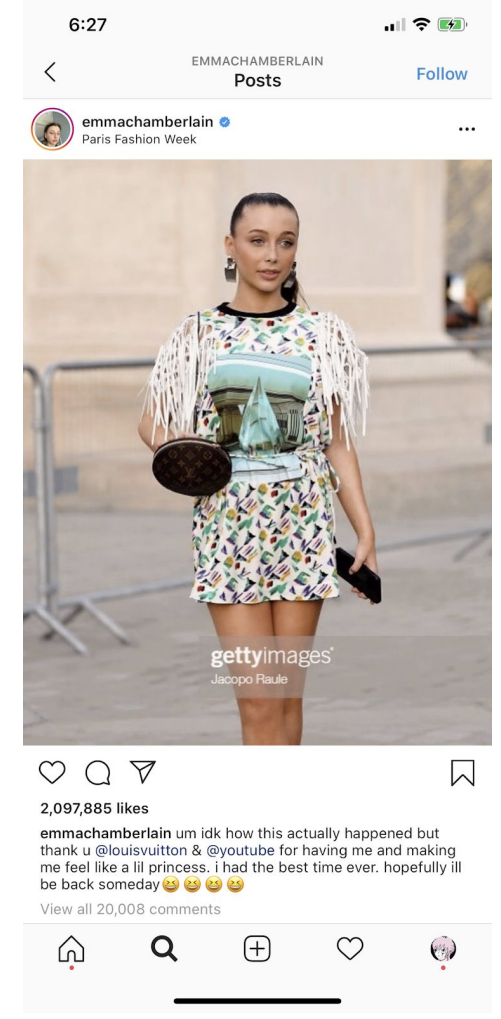




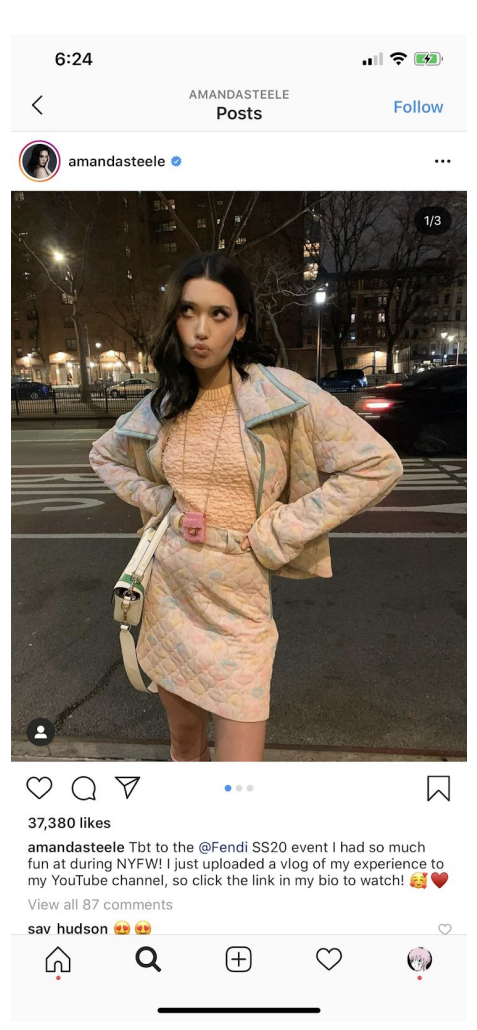

school under her name "MakeupByMandy". Since then, she has grown a lot and changed the name of the account to

"AmandaSteele" and rebranded herself into being a high fashion influencer. She has 2.1M followers and has partnered with Fendi, Ferragamo, Maybelline, and many more. More recently, she has launched her own clothing brand Steele, compared to most influencers making "merch" for themselves. Amanda designs clothes and followed her lifelong dream to be a fashion designer and create her own company, with competitors such as Ruve, I.AM.GIA, and more. The style of the clothing is similar to her personal style she displays on her social media platforms; dark and grungy yet soft and girly. I love this style and find it very similar to my own. Amanda films and posts the creative process behind her company on her Youtube channel, from designing, to prototypes, to dealing with manufacturers, to photoshoots, and more. Another self made influencer is 23 year old Joanna Kutcha. Joanna Kutcha came to light in 2014 posting viral pale "tumblr" photos with her boyfriend at the time, under the name "pixiejoanna". Tumblr was a very popular social media platform during that time and gave Joanna Kutcha the platform she has now. Since then, Tumblr is not as relevant and she has rebranded herself from a dark, edgy Tumblr icon to being a social media influencer with fun pastel clothing that is very $\mathrm{Y} 2 \mathrm{~K}$ and Clueless inspired, under the name "JoannaKutcha". Joanna has 1M followers and her target audience is young girls interested in "cute" girly alternative fashion. She has partnered with Jean Paul Gaultier, Puma, Missguided, and more with sponsored Instagram posts. Becoming a large self made influencer takes a lot of work, and luck, to make it where these women are today.

Contrasting self made influencers, there are many social media influencers who already had a platform before partnering with brands on sponsored posts. For example, a member of the Kardashian clan, is Kylie Jenner with 171M followers. Kylie has rebranded her platform from sponsored posts and photoshoots with companies to creating her own brands Kylie Cosmetics and Kylie Skin, to sell to her followers. Kylie is highly impressionable on the younger generation and there is a community of people who aspire to look like her. Naturally, Kylie honed in on this "desire to look like her" and began creating makeup people can buy and follow on her tutorials. With the creation of Kylie Cosmetics, Kylie Jenner surpassed everyone in her family, and became the world's youngest billionaire according to Forbes. Without the use of social media, and social media influencing and marketing, Kylie would have never made it to that point. Her sister Kendall Jenner, the highest paid fashion model in the industry, makes less money than her. Another social media influencer who had a platform 
prior to the age of Instagram is actress Selena Gomez. Selena Gomez is 27 years old and has $174 \mathrm{M}$ followers on Instagram. Selena Gomez used to be the most followed person on Instagram, but since then she has been passed by Ariana Grande, Christiano Ronaldo, and Dwayne The Rock Johnson. However, Selena Gomez has been an influencer targeting the age group of people who watched her on TV as a child. This makes her target audience 18-25 year olds, as she works with brands such as Coach. Like Kylie, she has also created her own cosmetics company, Rare Beauty.

As many influencers begin creating their platform on their own, they definitely need some assistance to take it to the next level. Top influencers may require managers, agents, financial advisers, stylists, photographers, and more to keep their page growing and innovative. According to Business of Fashion, "Brands will spend $\$ 10$ billion on influencer marketing this year, according to the market agency Mediakix. Some influencers charge as much as $\$ 100,000$ per Instagram post and are launching fashion lines and beauty brands that generate millions of dollars in sales. " (Lieber, 2020). This leads into something many popular influencers have in common: the creation of their own company. This way, they can create more revenue than just what they receive from sponsored Instagram posts. You also see this with many of my example influencers above, but also with the creation of Fenty Beauty by Rihanna, Jeffree Star Cosmetics by Jeffree Star, and more. Influencer brands have proven to be successful for many large influencers giving them more revenue than just their sponsored posts. Business of Fashion states "It's a crucial career step that can unlock fame and riches far beyond what social media stars earn from promoting other brands' products." (Fernandez, 2020). I myself have dabbled in creating my own brand called Sunday Best. I created a small collection of hoodies, t-shirts, and sweatpants just for the fun and experience of doing it. As I do not have many resources physically and financially, this was just a fun experimental project for me to do. I designed the pieces and had them printed by a friend of mine who runs a local print shop. I created the website
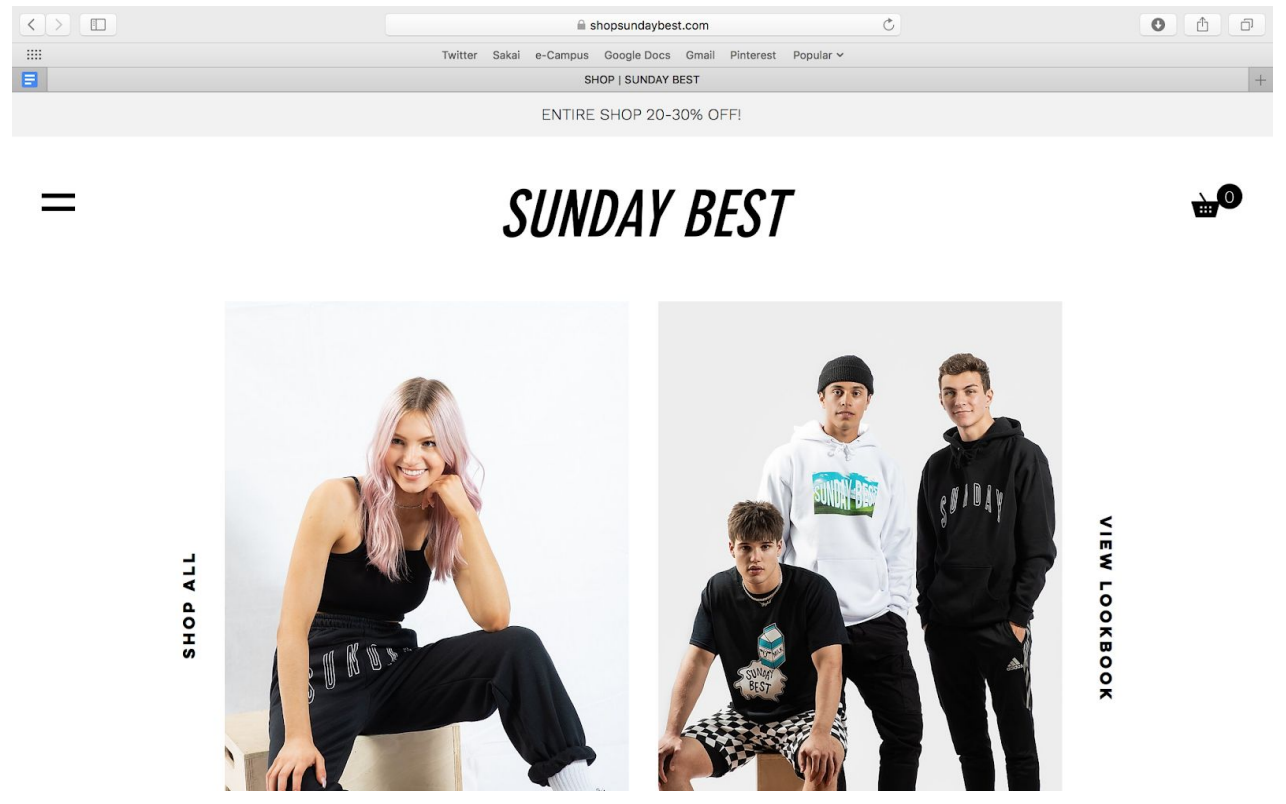

(shopsundaybest.com), as well as an Instagram page for the brand "sundaybestapparel". I organized a photoshoot with my friends and me as models, keeping the aesthetic of the brand very simple and clean. However, another way I build my business online is through Depop. 
Mentioned above, Depop is an online secondhand clothing shop formatted like a social media platform. It is described as "a digital vintage and streetwear fashion resale marketplace and has gained high awareness amongst individuals between 14 and 24 years of age in the UK" (Beney, 2019). As it is popular in the UK, Depop is a worldwide online marketplace and is now largely popular in the United States as well. You follow sellers and scroll through your feed like it is Instagram, and you can like and comment on products. You add the product to your cart, and

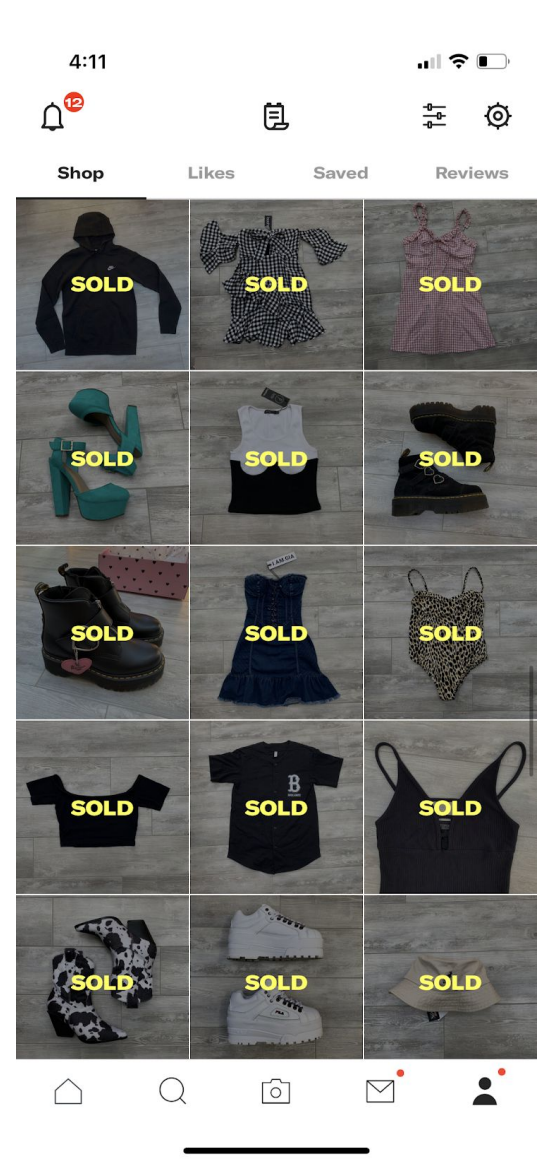
purchase it directly on the app. I advertise my Depop on Instagram frequently, so a bit of my followers have carried over. This is where I sell garments I have been given in brand deals, garments I simply do not wear anymore, or other things like shoes and bags. Depop is a sustainable way of giving your clothing another life, and being able to profit off of it. I am constantly keeping up with my Depop, adding new products, and staying active on the app. My business has definitely been affected during the COVID-19 crisis, despite my best efforts to sanitize and wash all products and packaging. I know I am not the only one, but it is definitely a setback. However, there are many things I can do to improve my personal social media platform as a business. I can work harder on creating more Tiktoks, as it is my most popular social media platform. Fashion videos on Tiktok are fairly popular, so I could begin to create those as well as my usual Tiktoks. More and more fashion brands are transitioning to Tiktok for marketing as well, beginning with Burberry creating their own viral Tiktok challenge. "Fashion brands are only just starting to test the waters with TikTok, which has rocketed to the top of the app charts with over one billion downloads, according to Sensor Tower, a mobile app data firm." according to Business of Fashion (Lieber, 2019). The more followers I gain on Tiktok, the more carry over to Instagram which could likely land me more deals. I could also begin reaching out to companies, rather than letting them reach out to me. This is a very common thing for Instagram influencers to do, however I never dabbled in it because this was something I started spontaneously and accidentally. Another way to build my platform is to create Youtube videos. This is how two out of the three of the self made influencers I named gained their platforms. Youtube is a great platform to post lifestyle hacks, fashion hauls, and much more. From this, you can build your social media presence even higher, as brands also sponsor Youtube videos as well as Instagram posts.

The influencer lifestyle can be something fun and casual to some people, while for others it can be their full time job and business. It definitely depends on how hard one is willing to work and the amount of effort they want to put in. As I have worked hard for my college degree in Textile Marketing at the University of Rhode Island, I cannot see myself as a full time influencer. However, it has been a great hands-on experience in fashion and social media which will help me advance in my career in the fashion industry. 


\section{Annotated References:}

Lieber, Chavie. "Fuelling the Influencer Machine: The Hidden Network Turning People Into Stars." The Business of Fashion, The Business of Fashion, 14 Jan. 2020, www.businessoffashion.com/articles/professional/influencer-marketing-influencer-manager-assis tant-careers.

This resource talks about the amount of people needed to be a successful, money-making influencer able to live off of money made on social media. You may need to look for managers, photographers, ghostwriters, and more, to properly get into this industry; and maybe even land you once in a lifetime fashion collaborations.

Fernandez, Chantal. "How to Launch an Influencer Brand in 2020." The Business of Fashion, The Business of Fashion, 4 Feb. 2020, www.businessoffashion.com/articles/professional/how-to-launch-an-influencer-brand-in-2020.

This resource talks about influencers creating their own brand. This is something almost all successful influencers end up doing, including the example influencers I will be mentioning in my paper.

Hutchinson, Andrew. "New Report Looks at the Growth of Influencer Marketing on Instagram." Social Media Today, 18 Dec. 2019, www.socialmediatoday.com/news/new-report-looks-at-the-growth-of-influencer-marketing-on-i nstagram-1/569277/.

This resource talks about the rise of social media influencing and how fashion is the most popular category with mostly millenial women influencers. It talks about how most established influencers are on the older side rather than younger, because it is essentially a business and requires experience.

Beney, Helen. "Depop the Social Shopping Platform: Developing the Business Model for International and Physical Expansion." Bloomsbury Fashion Business Cases. London: Bloomsbury Academic, 2019. Bloomsbury Fashion Central. Web. 10 Apr. 2020.

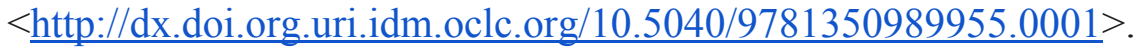

This resource talks about using Depop as a business tool. I use Depop daily to sell the excessive amount of clothes I receive from sponsored brand deals.

Lieber, Chavie. “Gen Z Loves TikTok. Can Fashion Brands Learn to Love It Too?” The Business of Fashion, The Business of Fashion, 13 June 2019, 
www.businessoffashion.com/articles/professional/gen-z-loves-tiktok-can-fashion-brands-learn-to -love-it-too.

This resource talks about the rise of Tiktok as a social media platform and how fashion brands need to use this app to their advantage.

Robehmed, Natalie. "At 21, Kylie Jenner Becomes The Youngest Self-Made Billionaire Ever.” Forbes, Forbes Magazine, 7 Mar. 2019, www.forbes.com/sites/natalierobehmed/2019/03/05/at-21-kylie-jenner-becomes-the-youngest-sel f-made-billionaire-ever/\#5649d7772794

This Forbes article describes the extent of Kylie Jenner's success she has attained from her business, TV show, and social media platforms.

Lieber, Chavie. "For Influencers, Affiliate Revenue Is Next to Disappear." The Business of Fashion, The Business of Fashion, 26 Mar. 2020, www.businessoffashion.com/articles/professional/exclusive-affiliate-links-cut-coronavirus-influe ncer-marketing.

This Business of Fashion article describes the trouble social media influencers may be in due to the COVID-19 pandemic. Companies are greatly cutting the costs of influencer marketing to save money during this time. 